Article

\title{
Feasibility and applicability of standardized and regular follow-up of sickle cell patients in a remote area of a developing country
}

\author{
Benoît Mukinayi Mbiya ${ }^{1,2}$, Didier Kalenda Kalombo ${ }^{1,2}$, Yannick Nkesu Mukendi ${ }^{1,2}$, Valery \\ Daubie $^{3}$, John Kalenda Mpoyi ${ }^{2}$, Parola Mukendi Biboyi ${ }^{2}$, Ghislain Tumba Disashi ${ }^{4}$ and Béatrice \\ Gulbis ${ }^{5, *}$.
}

1 Pediatrics Department, Faculty of Medecine, University of Mbujimayi, 06201, Mbujimayi, Democratic Republic of Congo; benoit.mbiya@um.ac.cd (B.M.M.); drkalombodidier@gmail.com (D.K.K.), yannicmukendi@gmail.com (Y.N.M)

2 Sickle Cell Referral Center, Clinique Pédiatrique de Mbujimayi - Pediatrics Clinic of Mbujimayi, 06201, Mbujimayi, Democratic Republic of Congo; johnmpoyi2@gmail.com (J.K.M.); parola.biboyi@cpmrdc.com (P.M.B.)

3 Clinical Biology Department, Laboratoire Hospitalier Universitaire de Bruxelles-University Laboratorium Brussel, Université Libre de Bruxelles, 1070 Brussels, Belgium. Valery.DAUBIE@lhub-ulb.be (V.D.)

${ }^{4}$ Internal Medecine Department, Faculty of Medecine, University of Mbujimayi, 06201, Mbujimayi, Democratic Republic of Congo; recteur@um.ac.cd (G.T.D.)

${ }^{5}$ Clinical Chemistry Department- Hereditary Red Blood Cell Disorders, Laboratoire Hospitalier Universitaire de Bruxelles-University Laboratorium Brussel, Université Libre de Bruxelles, 1070 Brussels, Belgium; Beatrice.GULBIS@lhub-ulb.be (B.G.)

* Correspondence: Beatrice.GULBIS@lhub-ulb.be

\begin{abstract}
Background: Sickle cell disease (SCD) is the most common hemoglobinopathy in the Democratic Republic of Congo (DRC) and poses a public health problem. If, without clinical followup, more than $50 \%$ of children with SCD die before their 5th birthday. A regular medical follow-up is the first simple improvement that can be beneficial for SCD patients in a remote city of an African country. Method: A cohort of 143 children with SCD aged 10 years old (IQR [inter quartile range]: 615 years) (sex ratio male: female $=1.3$ ) were clinically followed for 12 months without any specific intervention and then 12 months with a monthly medical visit, a biological follow-up and regular prophylaxis. A paired Student test and pairwise Wilcoxon test were used to compare study outcomes. Results: The median age of patients at the diagnosis of SCD was 2 years (IQR: 1-5). Anemia was noted in $100 \%$ of patients at inclusion, with severe and normocytic anemia in $80 \%$ of cases $(n=115)$. The implementation of standardized and regular follow-up has shown an increase in the annual mean hemoglobin level from the percentage of the low limit normal for the age from 54 to $77 \%(p=0.001)$, and a decrease of the lymphocytes count and spleen size $(p<0.001)$. The implementation of regular follow-up has also shown a significant decrease $(p<0.001)$ in the average annual number of hospitalizations and episodes with vaso-occlusive crises, blood transfusions, infections, and acute chest syndromes. Conclusions: This study showed that the regular follow-up of children with SCD and the application of SCD management recommendations are possible and applicable in the context of a remote city in a developing country. Simple and accessible measures included in conventional recommendations can reduce the morbimortality of these patients in remote areas if applied rigorously with regular follow-up.
\end{abstract}

Keywords: sickle cell disease. feasibility. regular follow-up. remote area. Democratic Republic of Congo 


\section{Introduction}

Sickle cell disease (SCD) is caused by a single-point mutation of the 6th codon (GAG6GTG), resulting in the replacement of glutamic acid by valine (Glu6Val) that promotes the polymerization of hemoglobin S and sickling of erythrocytes. Inflammation, hemolysis, microvascular obstruction, and organ damage characterize the clinical expression of the disease. Environmental and genetic factors influence many pathophysiological aspects of SCD. It is estimated that 305,800 babies are born each year with the disease worldwide, with nearly $75 \%$ of these births occurring in sub-Saharan Africa [1].

Despite this high incidence, established life-saving public health programs for SCD have not been implemented in most African countries. Consequently, childhood mortality due to the disease remains high and estimates suggest that, without interventions, up to $90 \%$ of individuals with SCD in Africa will not reach the age of 18[2].

After Nigeria, the Democratic Republic of Congo (DRC) contributes significantly to the high number of SCD patients in sub-Saharan Africa [1]. In DRC, the prevalence of the sickle cell trait in the population varies from $20 \%$ to $30 \%$ and the HBB S allele frequency in neonates varies from $0.96 \%$ to $1.4 \%$, with the annual number of newborns with SCD estimated to be 40,000 [3,4]. While these figures are significant from an epidemiological point of view, the disease remains little recognized, resulting in high mortality and morbidity [5,6]. Clinical manifestations of SCD are episodes of acute anemia, painful crises named vaso-occlusive crises (VOC), and susceptibility to infections [7]. SCD children who present with a severe clinical picture, such as repeated VOC, cerebral vasculopathy, acute chest syndrome, or severe chronic anemia, should benefit from one of the three treatments currently available: hydroxyurea, chronic blood transfusions, or stem cell transplantation. However, in sub-Saharan Africa, transfusions of red blood cells remain at risk of the transmission of infectious agents, and the transplantation of stem cells is not available. Due to the severity of the disease and the inaccessibility of chronic blood transfusions, SCD patients who could benefit from hydroxyurea in Africa are more frequent and this should be the subject of consensus [5]. However, this molecule remains hardly accessible in sub-Saharan Africa and its cost remains high [8].

The application of conventional management recommendations significantly improved the survival of SCD patients in developed countries [9]. These simple, accessible, and less costly principles accompanied by a regular medical monitoring would improve the health of SCD patients in sub-Saharan Africa if applied rigorously, like in developed countries. In developed countries, the survival increase and the better quality of life of SCD patients are less due to sophisticated therapeutics such as stem cell transplantation than to organized systems of early and adequate patient management $[10,11]$. The considerable improvement in the prognosis of SCD achieved by the teams of Serjeant in Jamaica, a country with limited resources, is a remarkable example which shows that, based on suitable strategies, the prognosis of SCD can be improved in Africa [11]. These strategies should include the creation of sickle cell referral centers and integrated care structures within health facilities, the establishment of sickle cell care networks, and the early diagnosis of associated complications by regular medical follow-up. Studies reported on SCD in Africa are mainly retrospective, hospital studies conducted in large cities and capitals. Prospective studies on the optimal follow-up of SCD patients with the rigorous application of management recommendations are rare in Africa [9]. This prospective study aims to provide data on the optimal follow-up of SCD patients in Mbujimayi-a remote city - in the province of Kasai Oriental in the DRC.

The results of our preliminary survey on "Knowledge and behavior of 50 Congolese families affected by SCD - a local survey - " showed that each first SCD child in the household had an average of 3.4 VOC per year, 4 episodes of fevers per year, received an average of 1.9 blood transfusions per year, and was hospitalized an average of 3 times per year; none had been treated 
with hydroxyurea and $98 \%$ of families concerned by SCD wanted the creation of a referral care center in Mbujimayi [12].

The use of this data motivated us to create a reference center for the treatment of SCD in Mbujimayi. It also convinced us to conduct a study that aims to demonstrate if a regular, standardized follow-up of SCD patients in a remote city of DRC is feasible and affordable. Subsequent objectives were to define the number of patients who could benefit from the intensification of treatment by hydroxyurea $(\mathrm{HU})$ and if all the tools would be in place to assure an adequate medical follow-up for those who would be treated by HU.

\section{Patients and Method}

\subsection{Study Context}

This study was conducted in Mbujimayi, which is the capital city of the province of Eastern Kasai in the Democratic Republic of Congo (DRC) (Figure 1). Moreover, it is the third-largest city in terms of population, after Lubumbashi. Mbujimayi's 2020 population is now estimated to be 2,525,263 (Mbujimayi population data 2020), with an area of $135.12 \mathrm{~km}^{2}$ and a population density of 12,441 inhabitants $/ \mathrm{km}^{2}$.

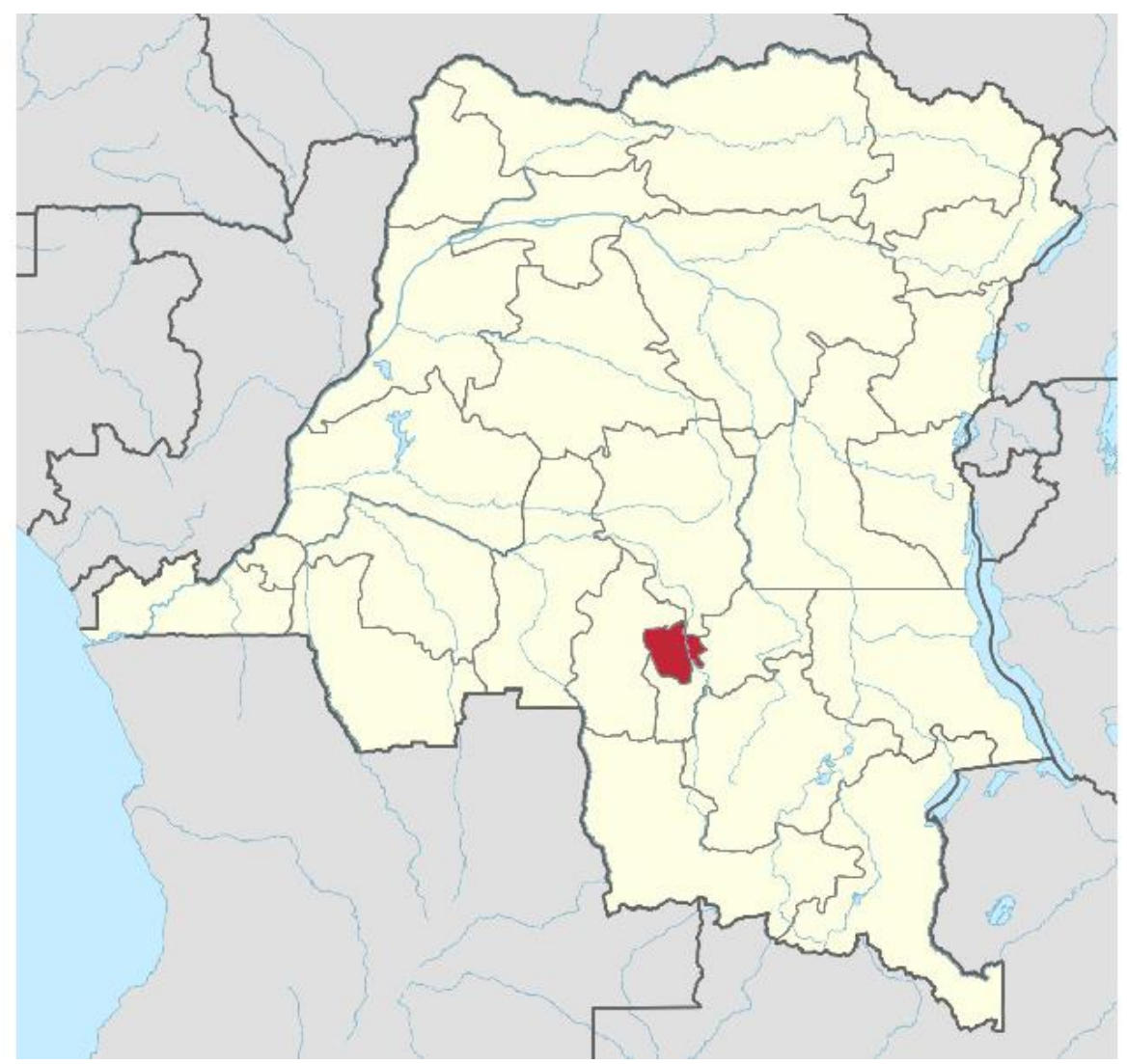

Figure 1. Location of the city of Mbujimayi on the map of the Democratic Republic of Congo (DRC)[13].

In DRC, SCD management is devoted to the National SCD Control Program (NSCP). In line with the strategy for strengthening the health system, the NSCP recommendations have not integrated SCD control activities in primary health care structures. The NSCP is also not implanted in Mbujimayi.

The study was carried out in the Mbujimayi Pediatric Clinic-one of the largest specialized pediatric structures and the only structure that organizes the management of SCD patients in 
Mbujimayi. It is a reference pediatric structure in the city of Mbujimayi, which is an Eastern Kasai province. It includes a pediatric ward with a capacity of 20 beds that are constantly occupied, a neonatology ward, a maternity ward, and a semi-automated laboratory.

\subsection{Study Type and Inclusion Criteria}

From January 2017 to December 2018, we conducted a prospective cohort study including SCD children. These children had never been followed and treated with hydroxyurea before their inclusion in the study. The follow-up of the cohort was 2 years, consisting of a first-year (2017) with a simple follow-up without the application of recommendations for the management of SCD and a second year (2018) with a follow-up of the same cohort with the application of international management recommendations.

Patients diagnosed with SCD (i.e., sickle cell anemia or sickle cell/Beta-thalassemia) who were older than 6 months and younger than 18 years were eligible for this study. The diagnosis of SCD was made using an Iso-electrofocusing test and/or an Emmel test associated with the presence of clinical features suggesting sickle cell anemia, i.e. a history of transfusion, or repeated bacterial infections or painful crises suggestive of an acute VOC. In addition, patients considered for inclusion had to reside in Mbujimayi during the study period. We excluded all SCD children whose primary guardian refused to sign the informed consent.

\subsection{Data Collection}

Data were collected during follow-up consultations using a data collection sheet for each patient. Then, these data were transcribed into a common database (Excel file).

\subsection{Study Parameters and Operational Definitions}

Socio-demographic parameters were age, sex, and age at the first diagnosis of SCD (made by a health care provider).

Clinical parameters were the origin of diagnosis (clinical and/or biological), weight $(\mathrm{kg})$, height $(\mathrm{cm})$, weight-for-height Z-score (WHO) assigned by sex and age, symptoms, and palpable size of the spleen. The splenomegaly was classified according to Hackett (WHO, 1963). VOC was defined as any painful episode requiring in-taking an analgesic (e.g. paracetamol, ibuprofen, or tramadol) or leading to a medical consultation in a health care structure. An infectious episode was defined as any noted increase in the body temperature beyond $38.5^{\circ} \mathrm{C}$ that needed to be managed in a health care facility. A red blood cells transfusion was defined as any administration of labile blood products (in particular, packed red blood cells or whole blood) that occurred in a health care facility. Acute chest syndrome was defined by the presence of fever, cough, chest pain, difficulty breathing \pm performing a chest $\mathrm{x}$ ray. Jaundice was a clinical observation i.e. the presence of a yellow coloration of the bulbar conjunctiva. Hospitalization was defined as an admission to hospital for treatment of at least 24 hours. Adherence to care was assessed as excellent, fair, or poor, depending on the clinical follow-up observed. A large city was defined as a city with an urban landscape, an international airport that is directly connected to foreign countries, while a remote city was defined as an urban-rural town in the country and having no direct contact with foreign countries. Anemia was define as a decrease in whole-blood hemoglobin concentration of more than 2 standard deviations below the mean of an age- and sex-matched reference range [14] 
Biological parameters were obtained by testing patients with an isoelectric focusing technique and a hemogram (excluding information related to reticulocyte counts). The biological parameters, especially the hemoglobin was used to evaluate the severity of the disease.

Therapeutic parameters consisted of medications taken. The criteria for prescribing hydroxyurea comprised three or more severe VOC occurring in the last 12 months, SCD-related pain or chronic anemia interfering with daily activities, and severe or recurrent episodes of acute chest syndrome $[15,16]$.

\subsection{Medical Monitoring}

Patients were subjected to a 2-year follow-up process comprising a monthly planned medical visit with clinical and hematological assessment. The first year period (2017) was undergone without the application of any recommendations, while the second year (2018) was organized with the systematic application of a standardized and regular follow-up (see Table 1).

Table 1. The standardized follow-up of sickle cell disease (SCD) and strategy for adhesion.

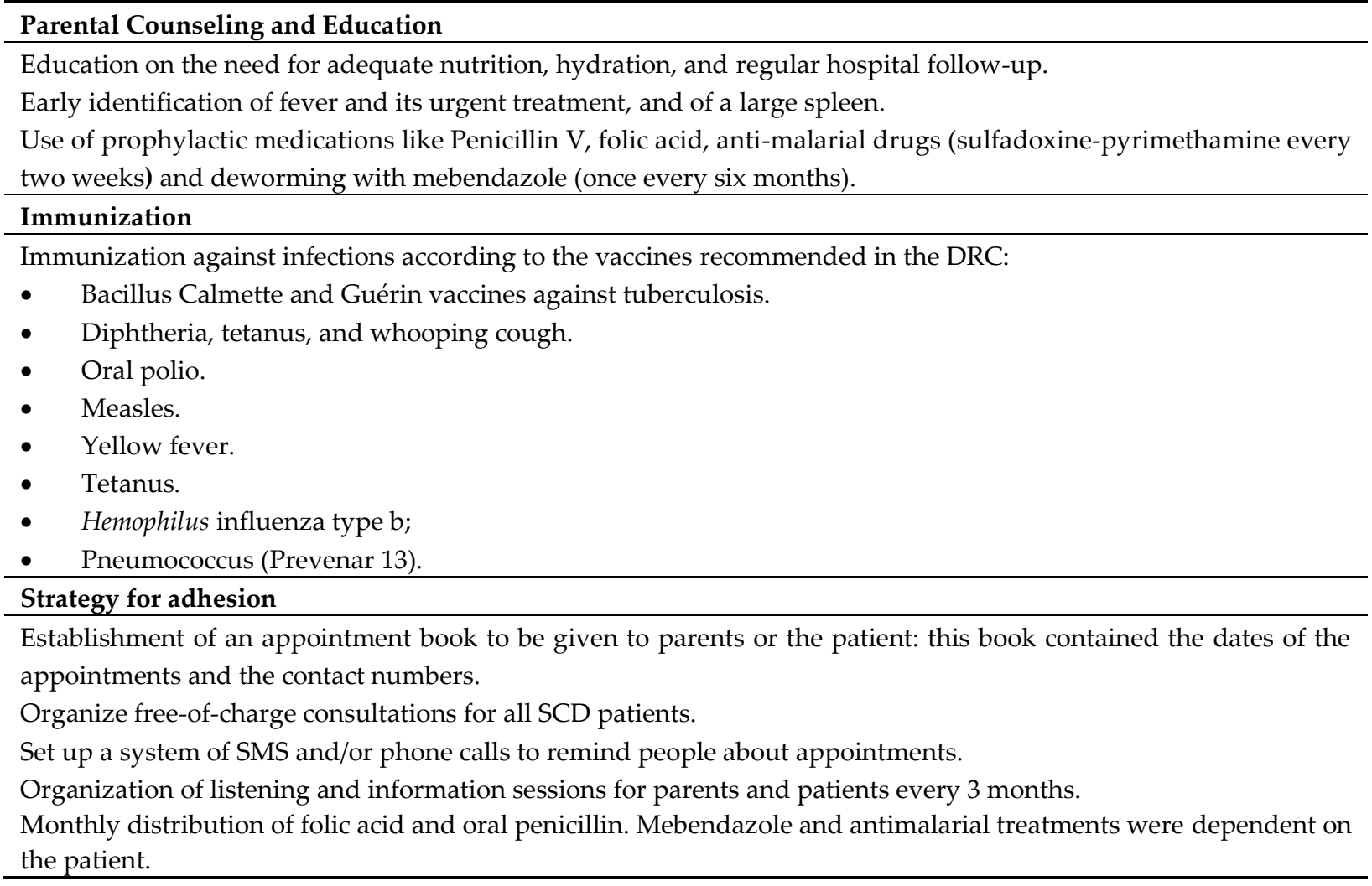




\subsection{Statistical Analysis}

In order to analyze blood parameters from children to adulthood patients, data were reported as the percentage of the lower normal limit for corresponding age. Because no criteria are defined for our area in Congo, normal values were compiled from neighboring regions [17-24]. Normal distribution was tested with the D'Agostino \& Pearson Normality test. Paired t-test (Gaussian data) or Wilcoxon matched-pairs signed-rank test (no Gaussian data) were used to compare data for each patient. Data were plotted within boxplot (2.5\% - 97.5\% range). Rate size evolution were analyzed with Chi-square test and relation between platelets count and rate size were analyzed by dividing platelets counts by a re-encoded rate size $(h 0=1, h 1=2, \ldots)$.

P-value $<0.05$ was considered as statistically significant $\left(\mathrm{p}<0.05={ }^{*}, \mathrm{p}<0.01={ }^{* *}, \mathrm{p}<0.001={ }^{* * *}\right)$ Statistical analysis were performed with Prism 8.0.1. (GraphPad Software Inc, San Diego, CA) software.

\subsection{Ethical Approval}

All parents or legal respondents of patients provided written informed consent for participation in the study. The study protocol had been reviewed and approved by the Ethics Committee of the Medical Faculty at the University of Mbujimayi (Fac-Méd/UM/CE/012/2016) and the Head Board of the Public Health Division of Eastern Kasai Province (DPSPN ${ }^{\circ 1 / 204 / C . E . P . D P S / K . O R / M B M / 2016) . ~}$ The study was conducted in agreement with the principles of the Helsinki Declaration II. The aim and procedures of the study were explained to the participants and legal respondents. The participants were informed that they could withdraw anytime, without further obligation. Anonymity of the participants was guaranteed, and no personal details were recorded. The results of this study were presented to parents and legal respondents during a discussion session at the end of the study.

\section{Results}

The process of the study and the recruited cohort of 143 SCD children are described in figure 2 and 3, respectively. Loss to follow-up and deaths rates during the first year period was $41 \%(104 / 251)$ and $1.6 \%(4 / 251)$, respectively. 


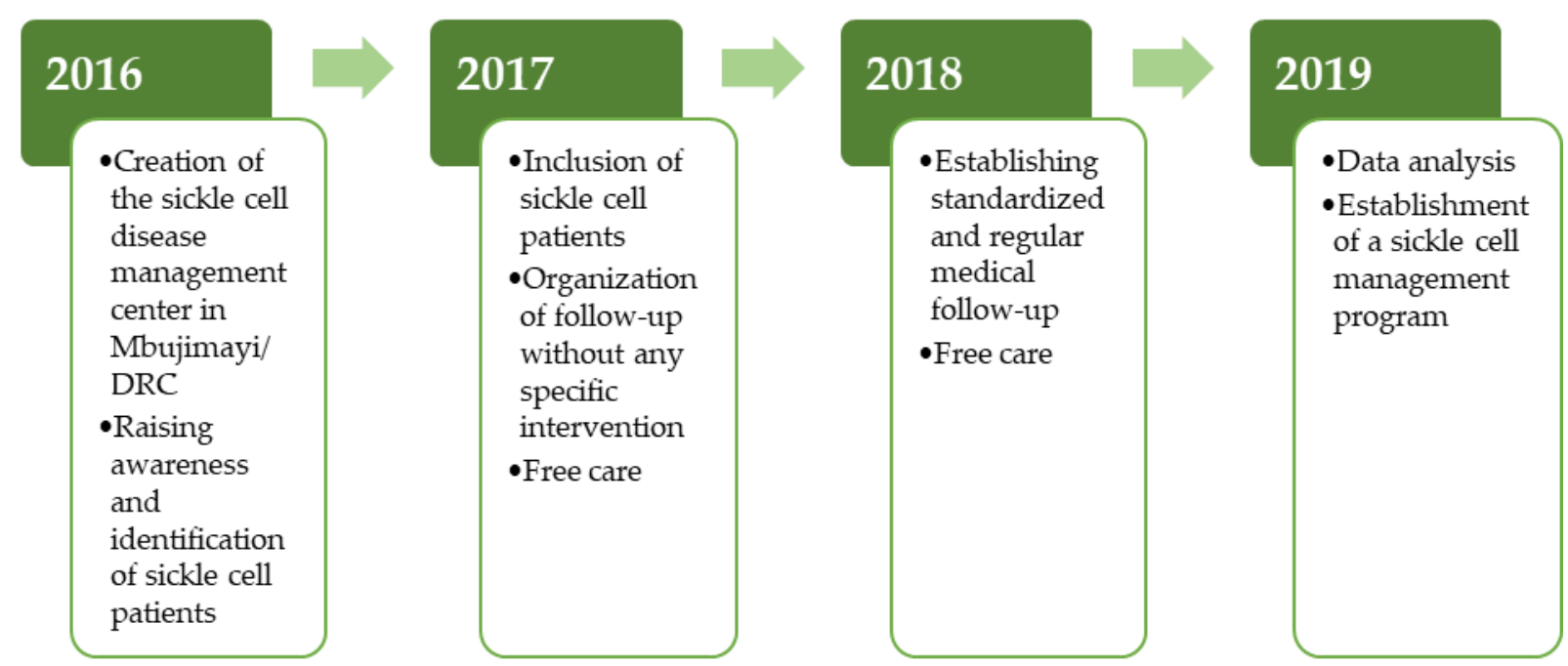

Figure 2. The overall evolution of the study on the application of standardized and regular Follow-up at Mbujimayi in $D R C$.

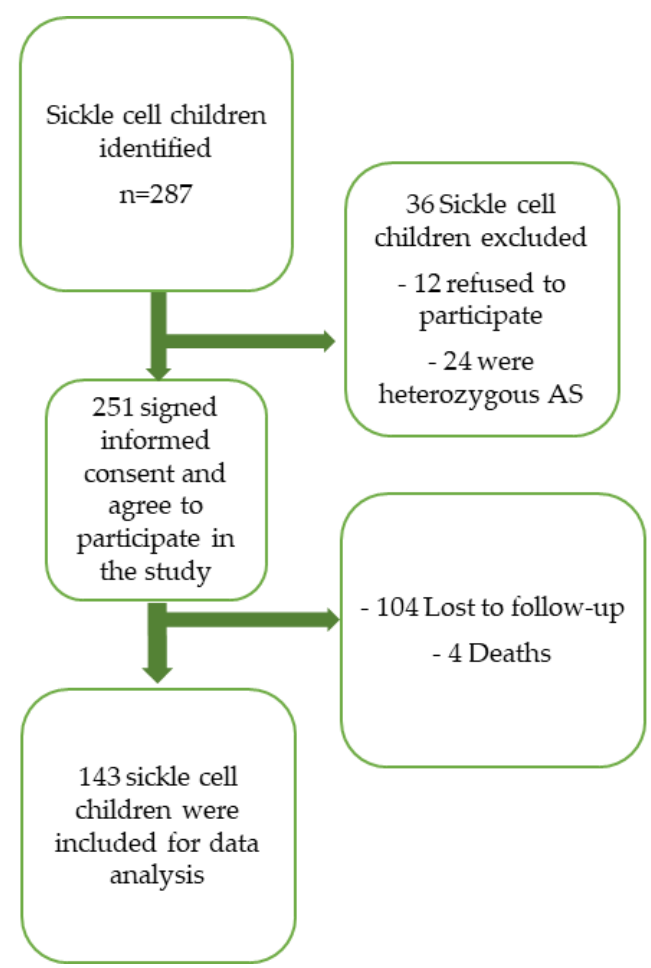

Figure 3. Inclusion of sickle cell children in the study.

The demographic and clinical characteristics of SCD children at 12 months of follow-up (FU) prior to the implementation of international recommendations are reported in Table 2 . The diagnostic means initially used was predominantly based on clinical features $(43 \%, 62 / 143)$. The circumstances of the diagnosis were mostly VOC (66\%) and anemia (18\%), and none were diagnosed during the neonatal period. The Z-score weight for height $<-2 \mathrm{DS}$ was observed in $47 \%$ of the patients. 
Table 2. Demographic and clinical characteristics of sickle cell children at 12 months of followup, prior to the implementation of sickle cell management recommendations $(n=143)$

\begin{tabular}{|c|c|c|c|}
\hline Variable & Median (IQR 25\%-75\%) & $\mathbf{n}$ & $\%$ \\
\hline Age & 10 (IQR: 6-15 Years) & & \\
\hline \multirow[t]{5}{*}{ Age at diagnosis } & 2 (IQR: 1-5 Years) & & \\
\hline & Before 1 year & 53 & 37 \\
\hline & Between 1 and 5 years old & 55 & 39 \\
\hline & Between 5 and 10 years old & 22 & 15 \\
\hline & After 10 years & 13 & 9 \\
\hline Sex & Female & 62 & 43 \\
\hline Schooling & Yes & 99 & 69 \\
\hline Z-score weight-for-height $<-2 \mathrm{DS}$ & Yes & 67 & 47 \\
\hline \multirow[t]{3}{*}{ Mode of first diagnosis } & Clinical & 62 & 43 \\
\hline & Electrophoresis of $\mathrm{Hb}$ & 44 & 31 \\
\hline & Emmel test & 37 & 26 \\
\hline \multicolumn{4}{|l|}{ Circumstances of first diagnosis } \\
\hline & Vaso-occlusive crisis & 94 & 66 \\
\hline & Anemia & 25 & 18 \\
\hline & Screening at the time of inclusion & 14 & 10 \\
\hline & Fever & 8 & 6 \\
\hline & Jaundice & 2 & 1 \\
\hline & Neonatal screening & 0 & 0 \\
\hline Confirmation of diagnosis by Iso electro focusing & Yes & 143 & 100 \\
\hline Chronic complications & Yes & 31 & 22 \\
\hline \multirow[t]{6}{*}{ Type of complications } & Hip arthritis & 13 & 11 \\
\hline & Stroke & 7 & 5 \\
\hline & Right eye blindness & 1 & 1 \\
\hline & Osteomyelitis & 4 & 3 \\
\hline & Leg ulcer & 3 & 2 \\
\hline & Other & 3 & 2 \\
\hline \multirow{4}{*}{ Reasons for hospitalizations } & Vaso-occlusive crisis & 45 & 31 \\
\hline & Infectious episodes & 34 & 24 \\
\hline & Anemia/blood transfusion & 24 & 17 \\
\hline & Other causes & 40 & 28 \\
\hline Presence of hepatomegaly & Yes & 86 & 60 \\
\hline Presence of jaundice & Yes & 126 & 88 \\
\hline Presence of splenomegaly & Yes & 98 & 69 \\
\hline \multirow[t]{6}{*}{ spleen measurement (according to Hacket) } & $\mathrm{H} 0$ & 45 & 31 \\
\hline & H1 & 16 & 11 \\
\hline & $\mathrm{H} 2$ & 34 & 24 \\
\hline & $\mathrm{H} 3$ & 24 & 17 \\
\hline & $\mathrm{H} 4$ & 15 & 10 \\
\hline & H5 & 9 & 6 \\
\hline
\end{tabular}

IQR: interquartile range, H0: Hackett stage 0 (no splenomegaly), H1: splenomegaly stage 1 of Hackett, H2: splenomegaly stage 2 of Hackett, H3: splenomegaly stage 3 of Hackett, H4: splenomegaly stage 4 of Hackett, H5: splenomegaly stage 5 of Hackett 


\section{Comparison of Data before and after the Implementation of a Standardized and Regular Follow-Up}

After one year of implementation of standardized and regular follow-up, an overall reduction of the annual average of clinical complications, i.e., VOC, infectious episodes, acute chest syndrome, blood transfusions and hospitalizations (Table 3a). Due to the variation in reference ranges of the considered biological parameters with age, to evaluate the evolution of those parameters their results were expressed as the percentage of the lower limit of reference range. A significant increase of hemoglobin level and platelet count were observed as well as a decrease of lymphocyte count. We did not observe statistical differences for the other hematological parameters. Anemia was observed in $100 \%$ of our cohort and it was severe and normocytic for 115 of them $(80 \%)$.

Table 3a Comparison of acute complications of sickle cell disease before and after the Implementation of a Standardized and Regular Follow-Up

\begin{tabular}{llll}
\hline & Year 1 & Year 2 & \multicolumn{1}{l}{$\begin{array}{l}\text { standardized and regular } \\
\text { follow-up n=143 }\end{array}$} \\
\cline { 1 - 2 } Clinical Parameters & $\begin{array}{l}\text { Follow-up without any } \\
\text { intervention n=143 }\end{array}$ & Annual average [IQR] & p-value \\
\hline Vaso-Occlusive Crisis & $3,9[1-6]$ & $1,1[0-2]$ & $<0,001(* * *)$ \\
\hline Infectious episode & $4,0[2-6]$ & $1,1[0-1]$ & $<0,001(* * *)$ \\
\hline Hospitalization & $3,8[2-5]$ & $1,2[0-2]$ & $<0,001(* * *)$ \\
\hline Acute Chest Syndrome & $1,0[0-1]$ & $0,0[0-0]$ & $<0,001(* * *)$ \\
\hline Blood Transfusion & $1,9[1-3]$ & $0,0[0-1]$ & $<0,001(* * *)$ \\
\hline
\end{tabular}

IQR: interquartile range (25\%-75\%), Significant $p$ values $(\leq 0,05)$ appear in bold. 
Table $3 \mathrm{~b}$ Comparison of biological parameters for sickle cell patients before and after the Implementation of a Standardized and Regular Follow-Up

\begin{tabular}{|c|c|c|c|}
\hline & Year 1 & Year 2 & \\
\hline \multirow[t]{2}{*}{ Biological Parameters } & $\begin{array}{l}\text { Follow-up without any } \\
\text { intervention }\end{array}$ & $\begin{array}{l}\text { Standardized and regular } \\
\text { follow-up }\end{array}$ & p-value \\
\hline & Median (\% LLN +/- SD) & Median (\% LLN +/- SD) & \\
\hline $\mathrm{HB}(\mathrm{g} / \mathrm{L})$ & $50(54 \pm 20)$ & $76(76 \pm 14)$ & $<0,001$ \\
\hline $\mathrm{RBC}\left(\mathrm{x} 10^{6} / \mathrm{mm}^{3}\right)$ & $2.0(64 \pm 25)$ & $2.9(86 \pm 19)$ & $<0,001$ \\
\hline HCT (\%) & $15(61 \pm 21)$ & $23(84 \pm 15)$ & $<0,00$ \\
\hline MCV (fL) & $81(129 \pm 20)$ & $82(125 \pm 13)$ & 0,176 \\
\hline $\mathrm{WBC}\left(\times 10^{3} / \mathrm{mm}^{3}\right)$ & $9.6 \quad(374 \pm 201)$ & $8.4(270 \pm 109)$ & $<0.001$ \\
\hline Lymphocytes (x 103/. $\left.\mathrm{mm}^{3}\right)$ & $4.1(364 \pm 293)$ & $3.2(239 \pm 145)$ & $<0,001$ \\
\hline Neutrophils $\left(\times 10^{3} / \mathrm{mm}^{3}\right)$ & $4.7(375 \pm 205)$ & $4.4(369 \pm 137)$ & 0,554 \\
\hline Platelets $\left(x 10^{3} / \mathrm{mm}^{3}\right)$ & $260(248 \pm 131)$ & $328(317 \pm 108)$ & $<0,001$ \\
\hline
\end{tabular}

HB: hemoglobin, RBC: red blood cells, HCT: hematocrit, MCV: mean corpuscular volume and WBC: white blood cells. Results of biological parameters expressed in percentage of the lower limit of reference range $(\% L L N) \pm S D$.

The therapeutic characteristics prior to the implementation of a regular follow-up are described in Table 4. None of the SCD children had been treated with hydroxyurea in the past. Applying the criteria for consensual indications of hydroxyurea treatment in the management of SCD, in the studied cohort $94 \%$ of SCD children had an indication for hydroxyurea treatment. Severe hemolytic anemia below $70 \mathrm{~g} / \mathrm{L}$ was the most common indication $(83 \%)$ for this treatment. The rigorous application of standardized and regular follow-up led to a 43\% reduction (94\%: 135/143 vs 51\%: $73 / 143)$ in the indications for treatment with hydroxyurea ( $p$-value $=0.05)$. 
Comparison of the evolution of splenomegaly one year before and one year after the implementation of standardized and regular follow-up showed a statistically significant difference (p-value $<0,001$ ) (see Figure 4).

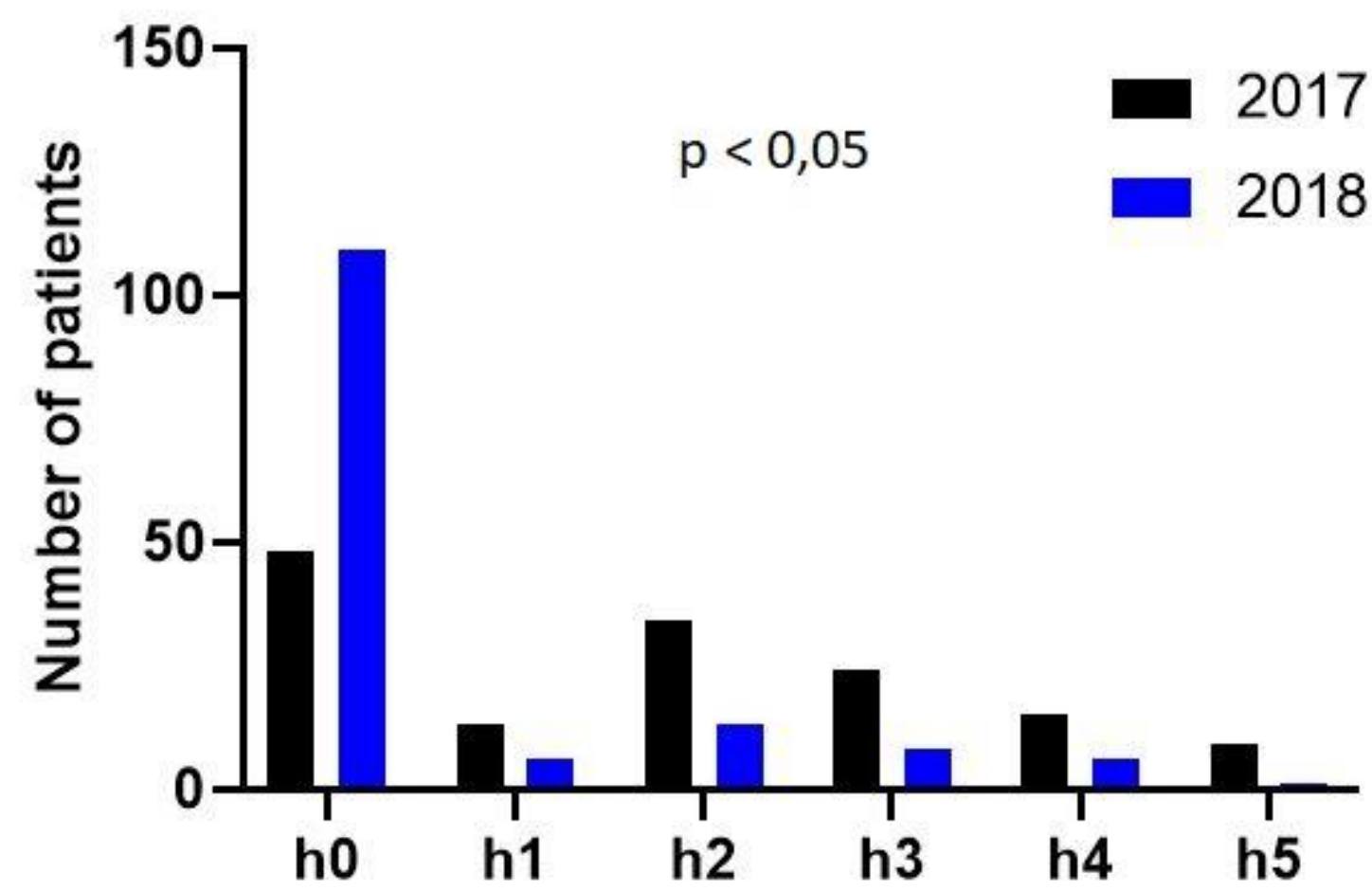

Figure 4: changes in spleen status in sickle cell patients in 2017 (followed without any medical intervention) and 2018 (standardized and regular follow-up). Figure shows statistically significant difference between 2017 and $2018(p<0,0001)$. The clinical classification of splenomegaly according to Hackett (WHO, 1963) includes 5 categories ranging from 0 to 5 :from non-palpable spleen, even in deep inspiration (category $0 ; h 0$ ) to spleen descending well below the navel, exceeding the line passing between the umbilicus and the pubic symphysis (category 5; h5). 
Table 4. Therapeutic characteristics prior to regular follow-up applying sickle cell management recommendations $(n=143)$.

\begin{tabular}{lcc}
\hline Variable & $\mathrm{n}$ & $\%$ \\
\hline Prophylaxis & 21 & 15 \\
\hline Folic acid and oral penicillin & 81 & 57 \\
\hline Routine vaccine & 0 & 0 \\
\hline Pneumoccocal vaccination $(23$ valent) & 0 & 0 \\
\hline Antimalarial & 0 & 0 \\
\hline Dewormers & 0 & 0 \\
\hline Hydroxyurea treatment & 96 & 67 \\
\hline Traditional treatment & 135 & 94 \\
\hline Indication for hydroxyurea treatment & 18 & 13 \\
\hline$\geq 2$ acute chest syndromes per year & 75 & 52 \\
\hline Vaso-occlusive crisis $\geq 3$ per year & 119 & 83 \\
\hline Severe anemia $<70 g / L$ & & \\
\hline
\end{tabular}

\section{Discussion}

This current study took place at the first support center for SCD created in Mbujimayi (around 2.5 million inhabitants) [25], which is a remote city located in the center of DRC. It aimed to organize an optimized follow-up process of SCD patients and to assess the efficacy of free care with the implementation of SCD management recommendations. A cohort of 143 SCD children with a median age of 10 years were followed for 2 years. The first year, without any specific intervention and the second year with a standardized and regular follow up. After 12 months of regular follow-up and parents' education without treatment intensification, an overall reduction of acute complications, i.e. vaso-occlusive crises, infectious episodes, acute chest syndrome, episodes of blood transfusions and hospitalizations, and an improvement of anemia, were observed. The results showed that the regular follow-up of SCD patients and the application of SCD management recommendations are possible and applicable in the context of a remote city in a developing country.

Creating a support center located close to patients that organizes free-of-charge care allowed the current study to be conducted. This is one of the recommended strategies for effectively reducing the burden of SCD morbimortality [6]. In the context of poverty, the goal of equal access to healthcare can only be achieved if health policies guarantee effective care for all patients. As described in Mali, providing centers and units of competence are vital [26]. These structures, whose missions focus primarily on diagnosis and management, should be local community centers. They are stepstones necessary to promote access to timely care for a great number of SCD patients and at an affordable cost. As reported by the Human Development Index, the majority of patients affected by SCD are those with a limited income [27] and in most African countries, only rich patients can have access to basic treatments, such as prophylactic oral penicillin, i.e. in DRC, the cost of SCD management is not affordable for approximately $95 \%$ of patients $[26,28]$. 
This study included SCD children for whom initial diagnosis was never reported being at birth. This initial diagnosis was mainly made based on clinical features only, especially the presence of VOC or anemia. These results are consistent with those of other authors who reported an average age of around 10 years in SCD patients and a first diagnosis at the age of 2 years or later [29-34]. VOC being also reported as the most frequent mode of first diagnosis [30,33,35,36].

In this study, patients were subjected to a 2-year follow-up process comprising a monthly planned medical visit with a clinical and hematological assessment. The first year period (2017) was undergone without the application of any intervention, while the second year (2018) was organized with the systematic application of a standardized and regular follow-up at monthly medical visits, including folic acid and daily oral penicillin prophylaxis, deworming, and antimalarial treatments, as well as a hematological assessment at each visit. In addition, a enhancing adherence process and education to prevent crises were implemented. The results of the first year of follow-up showed that sickle cell children without any specific medical intervention presented severe clinical and hematological pictures with an annual average of 4 VOCs, 4 infectious episodes, 1 acute thoracic syndrome, 4 hospitalizations demonstrating the severity of the disease in a remote area of a developing country. Annual averages of acute events and degradation of biological parameters similar to the results of this study among SCD patients who have not been followed-up in the past were reported in the literature $[12,30,33,37,38]$; however, those studies did not report the impact of a regular follow-up.

The application of standardized and regular follow-up during 12 months showed encouraging results, with a significant reduction in acute events of the disease i.e. a reduction in episodes of VOC, infectious episodes, blood transfusions, acute thoracic syndromes, hospitalizations and, an increase in the hemoglobin level and a decrease in the number of white blood cells due to lymphocytes. Studies carried out in industrialized countries have sufficiently demonstrated the benefits of standardized and regular medical follow-up of sickle cell patients, with reduction in acute and chronic complications of the disease and improvement in the quality of life [39-47]. Prospective cohort studies of SCD patients are rare in Africa due to barriers to medical monitoring [26]. However, a cohort study conducted in Benin in 2015 showed that the frequency of VOC were reduced to about one in every two years and some of the patients were crisis-free for as long as five years after implementing comprehensive health care management [48]. In Jamaica, the establishment of early diagnosis and simple prophylactic measures i.e. oral penicillin and parenting diagnosis of splenic sequestration, led to a significant reduction in SCD associated deaths [49]. A recent study conducted in a remote region of west India by a non-governmental organization reported the implementation a comprehensive SCD program in a secondary level hospital. They registered 404 SCD patients between December 2015 and June 2017 and compared the uptake of proven interventions and indicators of disease severity from one year prior to registration until the end of the study (June 2018). After the introduction of standardized and regular monitoring, they observed a statistically significant decrease in VOC (277 vs 53.4), hospitalizations number (49.8 vs 42.2) and blood transfusions (27.4 vs 17.8) [50]. As for our results, this demonstrates that the implementation of a comprehensive SCD management program can significantly reduce the severity of the disease.

Reasons for hospitalization were mostly, in descending order, VOC (31\%), infectious episodes $(24 \%)$, anemia $(17 \%)$. Similar studies reported that VOC or anemia are the leading cause of hospitalization $[32,37,50]$.

The implementation of standardized and regular follow-up showed a positive impact on the hemoglobin level from 50 to $70 \mathrm{~g} / \mathrm{L}$. The steady-state hemoglobin level of $50 \mathrm{~g} / \mathrm{L}$ before regular followup is lower than that reported previously in large cities of the DRC or other African countries $(70 \mathrm{~g} / \mathrm{L})$ $[29,30,33,52]$. It could be explained by the lack of optimal management of the disease in the past but also by other factors that should be explored. 
If $78 \%$ of SCD patients included in this study had an indication for HU treatment, after 12 months of regular follow-up, it was reduced to $54 \%$ of them. In a Nigerian study, $65 \%$ of 206 SCD patients had an indication for hydroxyurea treatment [53]. In the Indian series, the number of SCD patients

on hydroxyurea was increased from 4 to $98 \%$ after the implementation of a comprehensive program of management of sickle cell disease in a remote tribal area [50]. However, several studies have shown that all patients should receive treatment in view to prevent SCD complications $[8,16,44,54,55]$.

The size as well as the severity of the disease of our cohort could be the result of a selection bias. Data must be interpreted taking into account these two aspects. Even if free of charge, if the clinical expression is mild, families are unlikely to come to a medical center. A longer-term study will undoubtedly make it possible to approach these patients and to know the benefit of a comprehensive care program among this patient population.

Significant improvements in the morbidity and mortality rates for children with SCD in highresource countries such as the United States have been demonstrated with the implementation of a national newborn screening program, prophylactic therapy, comprehensive care programs including hydroxyurea therapy, and hematopoietic stem cell transplantation. Many of these interventions can confer the same benefits to SCD patients in Africa. Our future prospects are to continue the offer of regular and standardized care, but also to provide neonatal screening and hydroxyurea therapy. Neonatal screening provides many benefits like prevention of infection by an early start of antibiotic prophylaxis, folic acid, deworming, proper management of malaria, and immunizations against pneumococcal infections; it is feasible in Africa, but needs political support for its implementation [56]. The use of rapid sickle cell tests coupled with that of malaria and equipping reference centers with a confirmation technique i.e. iso-electrofocusing technique, could also be a strategy to take into account. Efficacy and therapeutic benefits of hydroxyurea have been widely documented. It remains the appropriate basic treatment in the management of SCD for African countries and this study proves that its side effects can be monitored $[6,8,8,39,44,54,57,58]$. A final perspective is to advocate at the government level for free care for all sickle cell children to guarantee regular follow-up.

\section{Conclusions}

The present study demonstrated that regular monitoring and the implementation of sickle cell disease management recommendations are possible and applicable in the context of a remote region of a developing country. Moreover, even if severely affected, within a 12 months follow-up period, SCD children benefited from a significant reduction in clinical complications. Simple and accessible measures included in conventional recommendations can reduce the morbimortality of these patients in remote areas if applied rigorously. In addition to these affordable interventions, hydroxyurea therapy is needed to decrease both SCD acute and chronic complications. The present study demonstrated also that its side effects monitoring is also feasible. Nevertheless, all this comprehensive care requires a strong public and private partnership to provide quality of care at a reasonable price for SCD patients in poor settings.

Author Contributions: Conceptualization, B.M.M. and B.G.; Methodology, B.M.M., G.T.D. V.D. and B.G.; Validation, B.M.M., G.T.D. and B.G.; Formal Analysis, V.D.; Investigation, D.K.K., J.K.M., Y.N.M. and B.M.M.; Resources, P.M.B.; Data Curation, V.D., P.M.B. and B.M.M.; Writing - Original Draft Preparation, B.M.M.; Writing - Review \& Editing, B.M.M. and B.G.; Visualization, B.M.M.; Supervision, G.T.D and. B.G.; Project Administration, B.G. 
Funding: This research received no external funding

Acknowledgements: We thank the parents for their cooperation and agreement for their participation in this study. We would also like to thank all the medical staff and laboratory staff at the Mbujimayi Pediatric Clinic for their active participation in the conduct of this study. We thank the "Fondation Roi Baudouin" in Belgium for its financial contribution, which largely contributed to the creation of the "Clinique Pédiatrique de Mbujimayi", without which this work would not have been possible (Conventions: 2015-I4811840-204333, 2016-I4811840205775, 2016-I1131070-206289)

Conflicts of Interest: The authors declare no conflict of interest

\section{References}

1. Piel FB, Hay SI, Gupta S, Weatherall DJ, Williams TN. Global burden of sickle cell anaemia in children under five, 2010-2050: modelling based on demographics, excess mortality, and interventions. PLoS Med. 2013;10(7):e1001484.

2. Wonkam A, Makani J. Sickle cell disease in Africa: an urgent need for longitudinal cohort studies. Lancet Glob Health. 2019 Oct;7(10):e1310-1.

3. Agasa B, Bosunga K, Opara A, Tshilumba K, Dupont E, Vertongen F, et al. Prevalence of sickle cell disease in a northeastern region of the Democratic Republic of Congo: what impact on transfusion policy? Transfus Med Oxf Engl. 2010 Feb;20(1):62-5.

4. Tshilolo L, Aissi LM, Lukusa D, Kinsiama C, Wembonyama S, Gulbis B, et al. Neonatal screening for sickle cell anaemia in the Democratic Republic of the Congo: experience from a pioneer project on 31204 newborns. J Clin Pathol. 2009 Jan;62(1):35-8.

5. De Montalembert M, Tshilolo L. [Is therapeutic progress in the management of sickle cell disease applicable in sub-Saharan Africa?]. Med Trop Rev Corps Sante Colon. 2007 Dec;67(6):612-6.

6. Mburu J, Odame I. Sickle cell disease: Reducing the global disease burden. Int J Lab Hematol [Internet]. 2019 [cited 2020 Jan 8];41(S1):82-8. Available from:

https://www.mendeley.com/catalogue/sickle-cell-disease-reducing-global-disease-burden/

7. Rees DC, Williams TN, Gladwin MT. Sickle-cell disease. Lancet Lond Engl. 2010 Dec 11;376(9757):2018-31.

8. Tshilolo L, Tomlinson G, Williams T, Santos B, Olupot-Olupot P, Lane A, et al. Hydroxyurea for Children with Sickle Cell Anemia in Sub-Saharan Africa. N Engl J Med [Internet]. 2019 Jan 1 [cited 2019 Jun 12];380(2):121-31. Available from: insights.ovid.com

9. Diallo DA. [Sickle cell disease in Africa: current situation and strategies for improving the quality and duration of survival]. Bull Acad Natl Med. 2008 Oct;192(7):1361-72; discussion 1372-1373. 
10. $\mathrm{S} D, G \mathrm{~B}, \mathrm{~W}$ W. A successful education program for parents of infants with newly diagnosed sickle cell disease. J Pediatr Nurs [Internet]. 1992 Feb 1 [cited 2020 Jan 21];7(1):52-7. Available from: https://europepmc.org/article/med/1548563

11. Serjeant GR, Serjeant BE. Management of sickle cell disease; lessons from the Jamaican Cohort Study. Blood Rev. 1993 Sep;7(3):137-45.

12. Mukinayi BM, Kalenda DK, Mbelu S, Gulbis B. Connaissances et comportements de 50 familles congolaises concernées par la drépanocytose: une enquête locale. Pan Afr Med J [Internet]. 2018 [cited 2018 Apr 6];29. Available from: http://www.panafrican-medjournal.com/content/article/29/24/full/

13. Mbuji-Mayi. In: Wikipedia [Internet]. 2019 [cited 2019 Dec 9]. Available from: https://en.wikipedia.org/w/index.php?title=Mbuji-Mayi\&oldid=917917895

14. Pomeranz AJ, Sabnis S, Busey S, Kliegman RM. Pediatric Decision-Making Strategies E-Book. Elsevier Health Sciences; 2015. 371 p.

15. Yawn BP, Buchanan GR, Afenyi-Annan AN, Ballas SK, Hassell KL, James AH, et al. Management of sickle cell disease: summary of the 2014 evidence-based report by expert panel members. JAMA. 2014 Sep 10;312(10):1033-48.

16. Sickle Cell Anemia Treatment \& Management: Approach Considerations, Hydroxyurea Therapy, Transfusion. 2020 Jan 31 [cited 2020 Mar 27]; Available from: https://emedicine.medscape.com/article/205926-treatment\#d8

17. Buchanan AM, Muro FJ, Gratz J, Crump JA, Musyoka AM, Sichangi MW, et al. Establishment of haematological and immunological reference values for healthy Tanzanian children in Kilimanjaro Region. Trop Med Int Health TM IH. 2010 Sep;15(9):1011-21.

18. Dosoo DK, Asante KP, Kayan K, Adu-Gyasi D, Osei-Kwakye K, Mahama E, et al. Biochemical and hematologic parameters for children in the middle belt of Ghana. Am J Trop Med Hyg. 2014 Apr;90(4):767-73.

19. Humberg A, Kammer J, Mordmüller B, Kremsner PG, Lell B. Haematological and biochemical reference intervals for infants and children in Gabon. Trop Med Int Health TM IH. 2011 Mar;16(3):343-8.

20. Kumwenda NI, Khonje T, Mipando L, Nkanaunena K, Katundu P, Lubega I, et al. Distribution of haematological and chemical pathology values among infants in Malawi and Uganda. Paediatr Int Child Health. 2012;32(4):213-27. 
21. Lugada ES, Mermin J, Kaharuza F, Ulvestad E, Were W, Langeland N, et al. Population-based hematologic and immunologic reference values for a healthy Ugandan population. Clin Diagn Lab Immunol. 2004 Jan;11(1):29-34.

22. Odutola AA, Afolabi MO, Jafali J, Baldeh I, Owolabi OA, Owiafe P, et al. Haematological and biochemical reference values of Gambian infants. Trop Med Int Health TM IH. 2014 Mar;19(3):275-83.

23. Quintó L, Aponte JJ, Sacarlal J, Espasa M, Aide P, Mandomando I, et al. Haematological and biochemical indices in young African children: in search of reference intervals. Trop Med Int Health TM IH. 2006 Nov;11(11):1741-8.

24. Santana-Morales MA, Quispe-Ricalde MA, Afonso-Lehmann RN, Berzosa P, Lorenzo-Morales J, Tiziano G, et al. Haemoglobin levels for population from Gambo, a rural area of Ethiopia, and their association with anaemia and malaria. Malar J. 2013 Dec 1;12:435.

25. Mbuji Mayi Population 2020 (Demographics, Maps, Graphs) [Internet]. [cited 2020 Jan 11]. Available from: http://worldpopulationreview.com/world-cities/mbuji-mayi-population/

26. Diallo DA, Guindo A. Sickle cell disease in sub-Saharan Africa: stakes and strategies for control of the disease. Curr Opin Hematol [Internet]. 2014 May [cited 2018 Oct 22];21(3):210-4. Available from: http://content.wkhealth.com/linkback/openurl?sid=WKPTLP:landingpage\&an=00062752201405000-00009

27. 2013 Human Development Report I Human Development Reports [Internet]. [cited 2020 Jan 21]. Available from: http://hdr.undp.org/en/2013-report

28. Batina SA, Kambale PK, Sabiti MP, Kayembe CT, Gulbis B. Barriers to health care for sickle cell disease patients in the Democratic Republic of Congo. Afr J Health Issues [Internet]. 2017 Dec [cited 2019 Feb 27];Volume 1 Issue 1:2. Available from: http://www.ajhissues.com/abstract.php?article_id=3475

29. Gbadoé AD, Atsou K, Agbodjan-Djossou OA, Tsolényanu E, Nyadanu M, Dogba AD, et al. [Ambulatory management of sickle cell disease: evaluation of the first year follow up of patients in the pediatric department of Lomé (Togo)]. Bull Soc Pathol Exot 1990. 2001 May;94(2):101-5.

30. Ayéroué J, Kafando E, Kam L, Gué E, Vertongen F, Ferster A, et al. [Hemoglobin sickle cell disease: experience of the Yalgado Ouedraogo University Hospital of Ouagadougou, Burkina Faso]. Arch Pediatr Organe Off Soc Francaise Pediatr. 2009 Apr;16(4):316-21.

31. Fernandes TAA de M, Medeiros TMD de, Alves JJP, Bezerra CM, Fernandes JV, Serafim ÉSS, et al. Socioeconomic and demographic characteristics of sickle cell disease patients from a 
low-income region of northeastern Brazil. Rev Bras Hematol E Hemoter [Internet]. 2015 May [cited 2018 Oct 23];37(3):172-7. Available from:

https://linkinghub.elsevier.com/retrieve/pii/S1516848415000596

32. Akodu S, Diaku-Akinwumi I, Njokanma O. Age at Diagnosis of Sickle Cell Anaemia in Lagos, Nigeria. Mediterr J Hematol Infect Dis [Internet]. 2013 Jan 2 [cited 2019 Mar 3];5(1). Available from: https://www.ncbi.nlm.nih.gov/pmc/articles/PMC3552728/

33. Aloni MN, Kadima BT, Ekulu PM, Budiongo AN, Ngiyulu RM, Gini-Ehungu JL. Acute crises and complications of sickle cell anemia among patients attending a pediatric tertiary unit in Kinshasa, democratic Republic of Congo. Hematol Rep. 2017;9(2):41-5.

34. Macharia AW, Mochamah G, Uyoga S, Ndila CM, Nyutu G, Makale J, et al. The clinical epidemiology of sickle cell anemia in Africa. Am J Hematol. 2017 Nov 23;

35. Thiam L, Dramé A, Coly IZ, Diouf FN, Seck N, Boiro D, et al. Profils épidemiologiques, cliniques et hématologiques de la drépanocytose homozygote SS en phase inter critique chez l'enfant à Ziguinchor, Sénégal. Pan Afr Med J [Internet]. 2017 Nov 7 [cited 2019 Feb 16];28. Available from: https://www.ncbi.nlm.nih.gov/pmc/articles/PMC5878839/

36. Alexandre-Heymann L, Dubert M, Diallo DA, Diop S, Tolo A, Belinga S, et al. Prevalence and correlates of growth failure in young African patients with sickle cell disease. Br J Haematol. 2019 Jan;184(2):253-62.

37. Kazadi AL, Ngiyulu RM, Gini-Ehungu JL, Mbuyi-Muamba JM, Aloni MN. The clinical characteristics of Congolese children and adolescents suffering from sickle-cell anemia are marked by the high frequencies of epistaxis compared to Western series. Pediatr Hematol Oncol. 2019 Aug;36(5):267-76.

38. Saidi H, Smart LR, Kamugisha E, Ambrose EE, Soka D, Peck RN, et al. Complications of sickle cell anaemia in children in Northwestern Tanzania. Hematology [Internet]. 2016 [cited 2020 Apr 29];21(4):248-56. Available from: https://www.mendeley.com/catalogue/b24cf166-b3ae3b4d-9561-2557d1685bae/

39. Ferster A, Vermylen C, Cornu G, Buyse M, Corazza F, Devalck C, et al. Hydroxyurea for treatment of severe sickle cell anemia: a pediatric clinical trial. Blood. 1996 Sep 15;88(6):19604.

40. Rincón-López EM, Navarro Gómez ML, Hernández-Sampelayo Matos T, Saavedra-Lozano J, Aguilar de la Red Y, Hernández Rupérez B, et al. Low-risk factors for severe bacterial infection and acute chest syndrome in children with sickle cell disease. Pediatr Blood Cancer. 2019;66(6):e27667. 
41. Quinn CT, Rogers ZR, McCavit TL, Buchanan GR. Improved survival of children and adolescents with sickle cell disease. Blood [Internet]. 2010 [cited 2020 Apr 29];115(17):3447-52. Available from: https://www.mendeley.com/catalogue/c2688465-4cd2-3b22-b1516bb1bf5f7063/

42. Gaston MH, Verter JI, Woods G, Pegelow C, Kelleher J, Presbury G, et al. Prophylaxis with Oral Penicillin in Children with Sickle Cell Anemia. N Engl J Med [Internet]. 1986 [cited 2020 Apr 29];314(25):1593-9. Available from: https://www.mendeley.com/catalogue/52236b28-1f4e3e4b-8af1-fe63f4857474/

43. Steinberg MH, Barton F, Castro O, Pegelow CH, Ballas SK, Kutlar A, et al. Effect of Hydroxyurea on Mortality and Morbidity in Adult Sickle Cell Anemia: Risks and Benefits Up to 9 Years of Treatment. J Am Med Assoc [Internet]. 2003 [cited 2020 Apr 29];289(13):1645-51. Available from: https://www.mendeley.com/catalogue/48107e65-38b5-3136-94538caacea1a7d4/

44. Voskaridou E, Christoulas D, Bilalis A, Plata E, Varvagiannis K, Stamatopoulos G, et al. The effect of prolonged administration of hydroxyurea on morbidity and mortality in adult patients with sickle cell syndromes: results of a 17-year, single-center trial (LaSHS). Blood. 2010 Mar 25;115(12):2354-63.

45. Shah N, Bhor M, Xie L, Paulose J, Yuce H. Sickle cell disease complications: Prevalence and resource utilization. PloS One. 2019;14(7):e0214355.

46. Lê PQ, Gulbis B, Dedeken L, Dupont S, Vanderfaeillie A, Heijmans C, et al. Survival among children and adults with sickle cell disease in Belgium: Benefit from hydroxyurea treatment. Pediatr Blood Cancer. 2015 Nov;62(11):1956-61.

47. Thomas R, Dulman R, Lewis A, Notarangelo B, Yang E. Prospective longitudinal follow-up of children with sickle cell disease treated with hydroxyurea since infancy. Pediatr Blood Cancer. 2019;66(9):e27816.

48. Odunvbun ME, Okolo AA. Implementing Comprehensive Health Care Management for Sickle Cell Disease in an African Setting. Niger J Paediatr [Internet]. 2015 Jan 1 [cited 2019 Sep 5];42(4):298-302-302. Available from: https://www.ajol.info/index.php/njp/article/view/122425

49. Lee A, Thomas P, Cupidore L, Serjeant B, Serjeant G. Improved survival in homozygous sickle cell disease: lessons from a cohort study. BMJ. 1995 Dec 16;311(7020):1600-2.

50. Dave K, Chinnakali P, Thekkur P, Desai S, Vora C, Desai G. Attrition from Care and Clinical Outcomes in a Cohort of Sickle Cell Disease Patients in a Tribal Area of Western India. Trop Med Infect Dis [Internet]. 2019 Oct 1 [cited 2020 May 14];4(4). Available from: https://www.ncbi.nlm.nih.gov/pmc/articles/PMC6958453/ 
51. Uyoga S, Macharia AW, Mochamah G, Ndila CM, Nyutu G, Makale J, et al. The epidemiology of sickle cell disease in children recruited in infancy in Kilifi, Kenya: a prospective cohort study. Lancet Glob Health [Internet]. 2019 Oct 1 [cited 2020 Jan 7];7(10):e1458-66. Available from: https://www.thelancet.com/journals/langlo/article/PIIS2214-109X(19)30328-6/abstract

52. Shongo MYP, Mukuku O, Mutombo AM, Lubala TK, Ilunga PM, Sombodi WU, et al. [Hematological and nutritional profile of homozygous sickle cell SS aged 6 to 59 months in Lubumbashi, Democratic Republic of Congo]. Pan Afr Med J. 2015;21:276.

53. Aliyu ZY, Babadoko A, Mamman A. Hydroxyurea Utilization in Nigeria, a Lesson in Public Health. Blood [Internet]. 2007 Nov 16 [cited 2020 Mar 27];110(11):80-80. Available from: https://ashpublications.org/blood/article/110/11/80/118231/Hydroxyurea-Utilization-inNigeria-a-Lesson-in

54. Luzzatto L, Makani J. Hydroxyurea - An Essential Medicine for Sickle Cell Disease in Africa. N Engl J Med [Internet]. 2019 Jan 1 [cited 2019 Jun 12];380(2):187-9. Available from: insights.ovid.com

55. Colombatti R, Palazzi G, Masera N, Notarangelo LD, Bonetti E, Samperi P, et al. Hydroxyurea prescription, availability and use for children with sickle cell disease in Italy: Results of a National Multicenter survey. Pediatr Blood Cancer. 2018 Feb;65(2).

56. Mulumba LL, Wilson L. Sickle cell disease among children in Africa: An integrative literature review and global recommendations. Int J Afr Nurs Sci [Internet]. 2015 [cited 2018 Oct 24];3:56-64. Available from: https://linkinghub.elsevier.com/retrieve/pii/S2214139115000207

57. Zimmerman SA, Schultz WH, Davis JS, Pickens CV, Mortier NA, Howard TA, et al. Sustained long-term hematologic efficacy of hydroxyurea at maximum tolerated dose in children with sickle cell disease. Blood [Internet]. 2004 Mar 15 [cited 2018 Oct 23];103(6):2039-45. Available from: http://www.bloodjournal.org/content/103/6/2039

58. de Montalembert M. [Hydroxyurea treatment in patients affected with sickle cell anemia: efficacy and safety]. Transfus Clin Biol J Soc Francaise Transfus Sang. 2008 Mar;15(1-2):34-8. 